\title{
2009 Dysphagia Research Society President's Report: Dysphagia Week Declared in New Orleans for the 17th Annual DRS Meeting
}

\author{
Benson T. Massey
}

Published online: 1 September 2009

(C) Springer Science+Business Media, LLC 2009

The Dysphagia Research Society held its 17th annual meeting March 5-7, 2009, at the Westin Canal Place in New Orleans, Louisiana. This multidisciplinary conference provided a forum for presenting cutting-edge research in deglutition and its disorders, while the preconference (March 4) provided updates on the applications of research findings to the care of patients with swallowing disorders.

Despite global economic concerns, a total of 299 participants attended this year's meeting. In keeping with the international scope of the Society, a total of 20 nations were represented.

Continuing with the trend of last year's meeting, a greater proportion of the meeting this year was devoted to original research. A total of 144 scientific abstracts were submitted, of which 38 were selected for presentation as oral papers and 82 as poster presentations. For the first time in the history of the DRS, the volume of abstracts submitted precluded presentation of all acceptable abstracts at the meeting. In response to suggestions from the membership, additional time was given for oral presentations and poster viewing. An innovation for this meeting was a Poster Plenary session on the final day of the meeting, involving brief discussions of the top posters selected by the Abstract Committee before the entire conference assembly. Another innovation was the introduction of a "Point-Counterpoint" forum wherein two discussants took opposing viewpoints on a topic of controversy. The two topics were "laryngopharyngeal reflux is overdiagnosed vs. underrecognized" and "swallow evaluations should begin

B. T. Massey $(\square)$

Division of Gastroenterology and Hepatology, Medical College of Wisconsin, 9200 West Wisconsin Avenue, Milwaukee, WI 53226, USA

e-mail: bmassey@mcw.edu with purees vs. liquids." The opportunity for the audience to participate in the postdebate discussion sessions proved integral to their success.

The setting of New Orleans, with its spicy cuisine, meshed perfectly with scientific themes specifically developed for this year's meeting. An important task for the Program Committee each year is to bring in new ideas and participants to the meeting. These researchers work in areas that at first glance might not appear dysphagia-related. However, their techniques and concepts have important implications for deglutition disorders and their investigation. In this regard, speakers and themes highlighted research that would be relevant to the sensory aspects of the swallowing mechanism. Topics ranged from mechanisms of degustation and nociceptive pathways to the effects of physical and flavor properties of food boluses on ingestive behavior. This information exchange exposed new researchers to the field of dysphagia, with the hope of stimulating and facilitating cross-disciplinary collaboration.

Mentoring the next generation of dysphagia researchers remains an important mission of the Society. At the meeting this mission was carried forward by sessions allowing junior investigators to meet with mentors and learn techniques for more effective presentations. Again, a session of the oral paper presentations was reserved for the top two young investigator-submitted abstracts. Fitting with the theme of mentoring, the DRS was honored to have a founding member, Walter J. Hogan, MD, present the Dodds-Donner Lecture on "The Dodds Legacy-The Man, the Mind, the Mentor."

Another mission of the DRS is to promote awareness of the importance of swallowing disorders and be an advocate for research of them. The Public Relations Committee had perhaps its greatest accomplishments in the Society's history during this year's meeting. After petitioning City Hall, 
the Committee got the Honorable Mayor Ray Nagin to declare "Dysphagia Week" in New Orleans to recognize the importance of the problem of dysphagia and the Society's efforts. Members of the Society discussed with the local media the importance of swallowing disorders. The relevance of food flavor and texture properties was put to the test as Society members sampled cricket hushpuppies and mealworm salsa at the Bug Appetit Café in the Insectarium Museum. Perhaps, most importantly, in a city whose academic programs were ravaged in 2005 by Hurricane Katrina, DRS speakers gave outreach lectures for Tulane University and Louisiana State University trainees, who were also invited to participate in part of the educational sessions of the annual meeting free of charge. Finally, for the first time, the PR Committee developed a DRS T-shirt with the important message "Support Dysphagia Research" emblazoned on the back.

The success of the 2009 meeting, reflected in the positive evaluations submitted by attendees, would not have been possible without the ongoing generous support of sponsors engaged in the field of dysphagia diagnosis, treatment, and education. Their commitment to the Society and its annual meeting will remain ever important in these challenging economic times. Accolades and thanks are also in order for members of the Program, Abstract, and Public Relations Committees for their high-quality work on this meeting. The Society has also been fortunate in having a strong partner in International Meeting Managers, without whose organizational skills the meeting would not have been possible. Last, but most important, the success of the meeting was the result of the Society's active members, who contribute not just with their wallets but also by bringing forward their best suggestions, research, and conviviality to share each year.

\section{President, Dysphagia Research Society}

Benson T. Massey, MD, FACP

\section{Board of Directors}

President Benson T. Massey, MD, FACP

President-Elect Gregory N. Postma, MD

Secretary-Treasurer Steven B. Leder, PhD

Past President Bonnie Martin-Harris, PhD, CCC-SLP, BRS-S

\section{Councilors}

Olle Ekberg, MD

Rosemary Martino, $\mathrm{PhD}, \mathrm{MSc}, \mathrm{MA}$
Susan G. Butler, PhD, CCC-SLP

Douglas J. Van Daele, MD

John C. Rosenbek, PhD, MS, CCC-SLP

\section{Archivists}

Bronwyn Jones, MD, FRACP, FRCR

Barbara C. Sonies, PhD, CCC-SLP, BRS-S

\section{Program Committee}

Benson T. Massey, MD, FACP, Chair

Joan C. Arvedson, PhD, CCC-SLP, BRS-S, BC-NCD

Stephanie K. Daniels, PhD, CCC-SLP, BRS-S

Caryn S. Easterling, PhD, CCC, BRS-S

Rebecca Z. German, PhD

Cathy L. Lazarus, PhD, CCC-SLP, BRS-S

Steven B. Leder, PhD

Ravinder K. Mittal, MD

Cathy A. Pelletier, PhD, MS, CCC-SLP

Gregory N. Postma, MD

John C. Rosenbek, PhD, MS, CCC-SLP

Catriona M. Steele, PhD, MHSc, S-LP(C), CCC-SLP, Reg. CASLPO

Douglas J. Van Daele, MD

\section{DRS Award Winners}

1st Place Paper Award Recipient

2nd Place Paper Award Recipient

3rd Place Paper Award Recipient

1st Place Poster Award Recipient

2nd Place Poster Award Recipient

3rd Place Poster Award Recipient

ASHA Div 13 Grant Recipient

Yul Brynner Grant Recipient

1st Place New Investigator Recipient

2nd Place New Investigator Recipient

Honorable Mention New Investigator Recipient

Michelle S. Troche, MA

Sri Naveen Surapaneni, MD

Jules Kieser, $\mathrm{PhD}$

Nobukazu Tanaka, DDS

Caroline Chandler

Fletcher Hietpas

Teresa Pitts, MA, CCC-SLP

Denise Barringer, MS, CCC-SLP

Julie Theurer, MClSc

Ianessa Humbert, $\mathrm{PhD}$

Koichiro Matsuo, DDS, $\mathrm{PhD}$

Benson T. Massey MD, FACP 